\title{
直流機延命化のための電機子巻線再含浸基礎特性および 遠赤外線照射の効果について
}

\author{
非会員 清川 晋* 非会員 井上 晴雄* \\ 正員 廣瀬 治男** 正員 森田 登**
}

Experimental Study of Re-impregnation Characteristics for Aged DC Machine and Effect of Application of Far Infrared Radiation to the process

Shin Kiyokawa*, Non-member, Haruo Inoue*, Non-member, Haruo Hirose**, Member, Noboru Morita**, Member

Recently hundreds of large dc machines manufactured for steel rolling mills at the high growing period are on the verge of replacement due to insulation deterioration of their armature windings after more than thirty years of service operation. Insulation technologies for aged machine are different from those for new machine, including varnish impregnation technologies.

In this paper, experimental study of basic impregnation characteristics for aged dc machine to extend its life is described.

Experimental study of application of far infrared radiation for the process is also presented.

キーワード : 直流機, 圧延用電動機, 絶縁劣化, 延命化, 絶縁システム, ワニス含浸, 遠赤外線

Keywords: DC machine, rolling mill motor, insulation deterioration, life extension, varnish impregnation, far infrared radiation

\section{1. まえがき}

現在 , 図 1 に示されるように高度成長期に製作された多 数の大形直流機が, 30 余年の稼動を経て, 寿命時期に近づ いている。これら大形直流機の寿命は電機子コイルの絶縁 劣化で決まるため劣化したコイルの絶縁特性を回復させ， 絶縁寿命の延伸を期待できる新しい処理技術の開発が望ま れている。一方，交流電動機では経年使用機の絶縁劣化状 況を考慮した再真空含浸法が，延命化の手法として広く利 用されている。本会技術報告第 594 号にもあるとおり直流 機では必ずしも成功していない。光の理由は, 直流機の電 機子コイルには, 整流子が有るため多数の口出し部分があ り，一旦真空含浸されたワニスが樹脂硬化のための乾燥過 程で流出してしまうのかと現在考えられている ${ }^{(1)}$ (3)。

本論文では以上のような経緯から，経年劣化機の枯れた 絶縁層に，より確実な再含浸を図ることに視点をおいて， 絶縁ワニスの基礎特性を実験研究したものである。あわせ

\footnotetext{
*ミサト (株)

干 340-0124 幸手市上宇和田 521-18

Misato-plaheat Co. Ltd.

521-18, Kamiuwada, Satte-shi 340-0124

** 日本工業大学

干 345-8501 埼玉県南埼玉郡宮代町学園台 4-1

Nippon Institute of Technology

4-1, Gakuendai, Miyashiro-machi, Saitama 345-8501
}

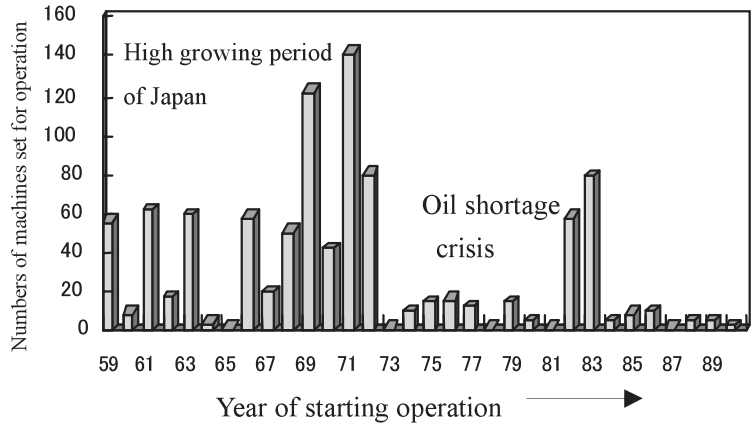

図 1 我国の圧延用大形直流機の稼動年別設置状況

Fig. 1. Historical trend of starting numbers of large DC mill motors for operation in Japan.

て，ワニス流出の口出し部への漏止め作用と，より均質な ワニス硬化を期待して, 遠赤外線の利用についても光の適 用性の検討を行ったので，弚の結果を報告する。

\section{2. ワニスの表面張力と浸透特性試験}

〈2 1〉 試験の背景 直流機に限らず電気機器のコイ ルは, 絶縁が複数層からなっており, 絶縁の各層はガラス テープ (又はシート) もしくはマイカガラステープ (又は シート) に，ワニスを含浸・硬化させて構成している。絶 縁劣化が進むと，熱劣化によって樹脂を構成する高分子が 分解していくのに加えて, 機械的摩耗も生じ, 兴の両者に 


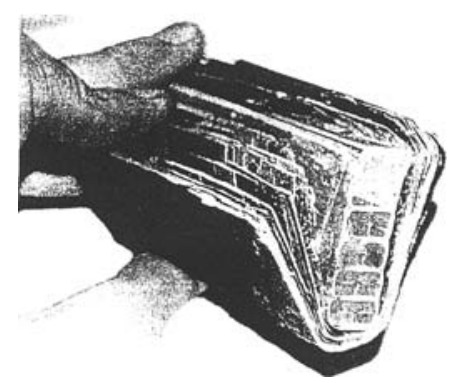

図 2 絶縁劣化したコイルに生じる絶縁層間の录離

Fig. 2. Peel between insulation layers in aged coil.

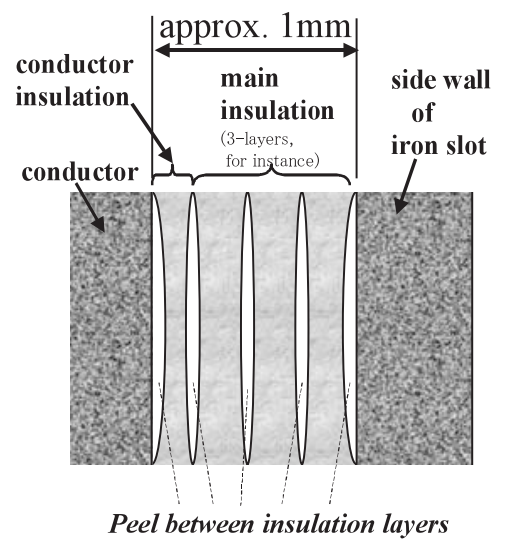

図 3 絶縁層間录離の概念図

Fig. 3. Schematic illustration of peels between insulation layers.

よって絶縁層は瘦せていくため，絶縁層の層間が渌離して 隙間ができる状態になると考えられる。経年使用後のコイ ルを取り出して調査した例でも，図 2 のようであって，コ イルの絶縁層間の剥離が明らかである ${ }^{(4) \sim(7) 。 ~}$

このコイルの絶縁層間の剥離のために出来るギャップの 概念図を図 3 に示す。図は電機子コイルの場合で, 絶縁層 は導体に接する素線絶縁層と主絶縁層 (図の場合は 3 層) からなっている。導体と素線絶縁層の剥離，絶縁層間の剥 離，主絶縁最外層と鉄心との間の录離を考慮すると，導体 と鉄心との間に 5 ヶ所の剥離層が存在し得る。

絶縁層の厚みは大形機の場合約 $1 \mathrm{~mm}$ と見ることができ るので, 絶縁劣化により絶縁層が例えば 10\%瘦せた場合を 考えると，合計 $100 \mu \mathrm{m}$ の剥離が発生することになる。こ の $100 \mu \mathrm{m}$ が 5 ヶ所の剥離層で均等に発生した場合には 1 箇所あたり $20 \mu \mathrm{m}$ となる。

電機子コイルの絶縁層には, 常時, 半径方向ならびに接 線方向に , ブラシ圧力程度の面圧か繰返し加わっているの で, 剥離のギャップが大きい場合には，フレッティング摩 耗 (吒かれ摩耗) の二次的絶縁劣化の段階に発展し，以降 急速に絶縁耐力が低下する。

従って絶縁層の剥離が過大となって二次的絶縁劣化の段 階に移行する前に , 真空含浸などの再含浸によって瘦せた 絶縁層にワニスを充填し，絶縁特性を回復することによっ て，延命化を図ることができると考えられる。

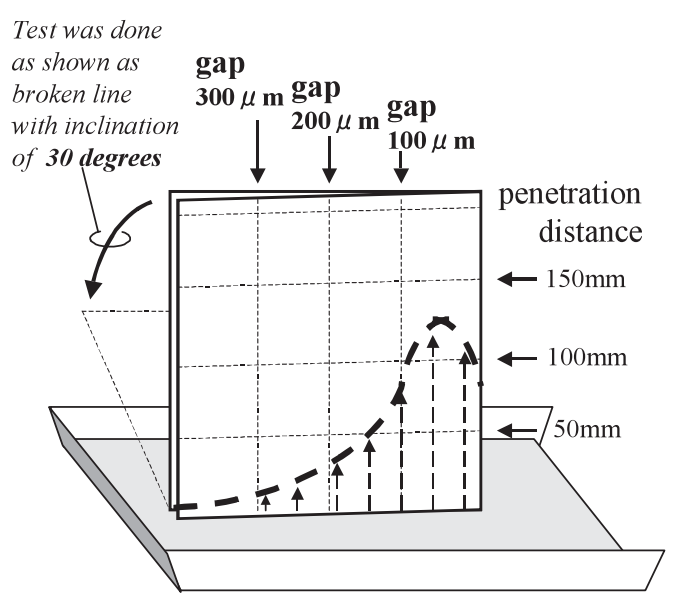

図 4 表面張力とワニスの浸透速度の試験装置

Fig. 4. Testing set-up for varnish surface tension and varnish impregnation speed into tapered gap.

〈2 2〉 ワニスの表面張力と浸透特性の試験装置 以上 から，絶縁層は，絶縁劣化の進行により層状に录離するこ と,および絶縁層間の剥離により生じた $20 \sim 50 \mu \mathrm{m}$ の極め て小さなギャップにワニス含浸させる必要があることが明 らかになった。

劣化により生じた剥離層にワニスを再含浸する場合，ワ ニスの浸透抵抗を表現する浸透距離一浸透時間の推定式等 により，含浸時間を的確に設定する必要がある。

またワニスを加熱硬化するとき硬化途中で過渡的に生じ る粘度低下によるワニス流出についても予め推定評価して 対策か講じられることか望ましい。

硬化途中の過渡的な粘度低下でワニスが流出する場合， ワニスの表面張力がどの程度流出防止に寄与しているかを 見積もる必要もある。

以上から微小ギャップへのワニスの浸透特性とワニスの 表面張力が同時に検証できる装置として図 4 のような試験 装置を考案・作製した。

図 4 の試験装置は,プリント基板の空板として市販されて いる $2 \mathrm{~mm}$ 厚ガラスエポキシ板を 2 枚使用してギャップを 構成したものであるが, ギャップはテーハ状になっていて，

例えば , 図の右端から $50 \mathrm{~mm}$ の場所のギャップは $50 \mu \mathrm{m}$ ， $100 \mathrm{~mm}$ の場所のギャップは $100 \mu \mathrm{m}$ であってワニスの浸透 速度とギャップ長の関係が直視できるようにしてある。

また図 4 の試験装置では，ワニスの表面張力がギャップ への浸透力になっており，ワニスが浸透していくと浸透し たワニスの重量と表面張力が最終的に釣合うので, ワニス の表面張力を計測する試験装置にもなっている。

ガラスエポキシ板を使用したのは, 実機コイルがガラス テープにエポキシワニスを含浸して構成するので， ワニス は異なるものの，実機コイルへのワニスの浸透と近似した 特性を示すと考えたからである。

なお図は直立になっているが, 実際には装置を支える都 合で, 水平から 30 度の角度に傾けて試験を行い, 光の結果 の評価では直立に換算している。 
〈2 3〉 表面張力の評価 実験は市販の含浸用エポキシ ワニスを用い，低粘度試料 (0.4 ポアズ) と高粘度の試料 (15.3 ポアズ) を用意して行った。また表面張力の比較対 象として，弚の特性がよく知られている $20^{\circ} \mathrm{C}$ の水でも試 験を行っている。

図 5 に試験結果を示す。これは表面張力と浸透したワニ スの重量が釣り合って，弚れ以上の浸透が停止した時点で 観測した結果である。本試験の結果は，理論的には図上で 直角双曲線になるが, 実験結果は, 水もワニスも $20 \mu \mathrm{m}$ の 所にピークがある。ギャップの小さい領域では，表面粗さ のため抵抗が大きくなるので極大值があると考えられる。 $20 \mu \mathrm{m}$ の所のピーク值は

$$
\begin{array}{lll}
\text { 水 } & : 110 \mathrm{~mm}, & \text { 比重 } 1 \\
\text { ワニス }(0.4 \text { ポアズ }) & : 200 \mathrm{~mm}, & \text { 比重 } 1.15 \\
\text { ワニス }(15 \text { ポアズ }) & : 190 \mathrm{~mm}, & \text { 比重 } 1.15
\end{array}
$$

である。この浸透深さの比と比重の比を考えると，ワニス の表面張力は水の 2 倍と見積もることが出来る。

この結果から算出される表面張力は, 両側で

$$
\text { 水 } \quad 10.8 \mathrm{dyn} / \mathrm{cm}(0.0108 \mathrm{~N} / \mathrm{m})
$$

ワニス $21.6 \mathrm{dyn} / \mathrm{cm}(0.0216 \mathrm{~N} / \mathrm{m})$

また次項の浸透性の検討でハーゲンポオアズイユの式を 使う関係から，圧力 $\Delta P$ に換算すると

$$
\text { 水 }: 55 \mathrm{~mm} \mathrm{Aq}(0.54 \mathrm{kPa})
$$

ワニス : $110 \mathrm{mmAq}(1.08 \mathrm{kPa})$ 注) $100 \mathrm{kPa}: 1$ 気圧 となり, 電動機の冷却ファンの吐出圧力にある数値と比較 すると意外に大きいことが分かる。

〈2.4〉 ワニス浸透性の評価と理論検討 图 6 , 図 7 に 0.4 ポアズワニス, 15.3 ポアズワニスの浸透経過を示す。図 は $20 \mu \mathrm{m}$ ギャップに所での浸透速度を横軸に浸透距離 , 縦 軸に浸透時間をとって示したもので，実測値とともに理論 式からの算定値が示されている。

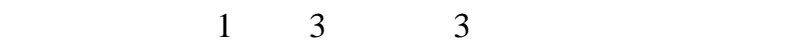
較する。いずれも任意の浸透距離に達する時間を求める式 である。これらは，

（1） ギャップを円管であるとしてハーゲンポアズイユ の式から導いた式

(2) ギャップ間口がギャップ長に対して十分に広い平

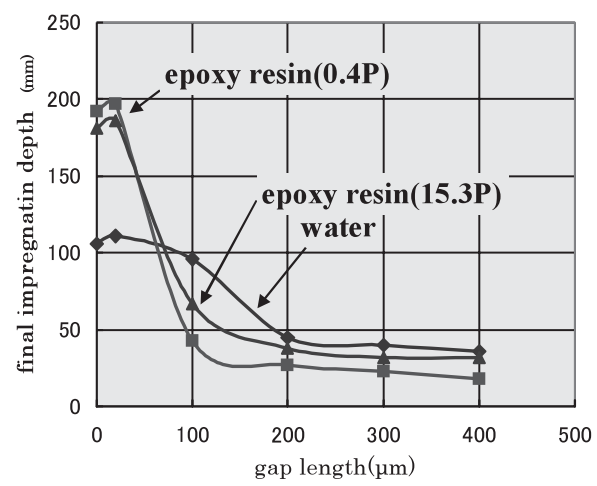

図 5 表面張力によるテーパーギャップヘのワニスの浸透 Fig. 5. Varnish impregnation into tapered gap by surface tension.
行ギャップとして機械設計便覧等で知られている式 からの高次の項を無視して導いた式

(3) ワニスの浸透につれて浸透したワニスの重量がワ ニスの浸透速度を低下させることを考慮した式 の 3 種類である。

なお，以上の式に誘導過程を付録に示す。

図 6 , 図 7 から表面張力によるワニスの浸透時にワニス の重量による浸透速度の低下を考慮した理論式は実測とよ く一致することがわかる。

このことは，理論式の仮定として用いられている矩形管 のモデルが円管のモデルより適切であることを裏付けてい る。円管のモデルでは 10 倍程度浸透速度が遅く見積もら れる理由は, 円管では流速の速度勾配が円管の断面の左右 上下に存在するのに対して，絶縁層の剥離を模擬した幅広 の矩形管の場合にはギャップ方向に速度勾配があるものの， 幅方向には速度勾配が少ないためと考えられる。

〈2.5〉 試験結果から得られる知見以上の試験結果 から得られた剥離ギャップヘのワニス浸透性推定式によっ

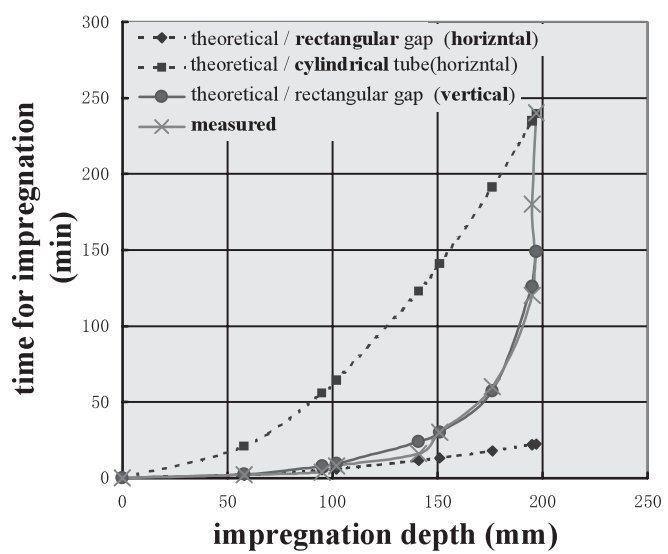

図 $620 \mu \mathrm{m}$ ギャップヘの 0.4P エポキシの浸透の理論 と実験

Fig. 6. Theoretical \& experimental results of $0.4 \mathrm{P}$ epoxy resin impregnation into $20 \mu \mathrm{mm}$ gap.

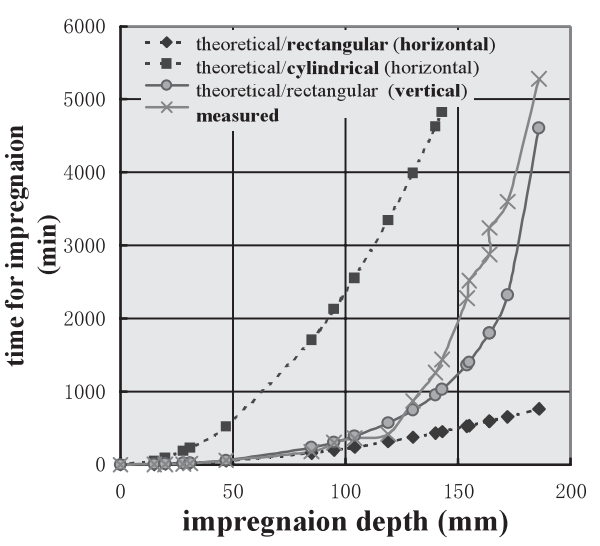

図 $720 \mu \mathrm{m}$ ギャップへの 15.3P エポキシの浸透 の理論と実験

Fig. 7. Theoretical \& experimental results of 15.3P epoxy resin impregnation into $20 \mu \mathrm{mm}$ gap. 


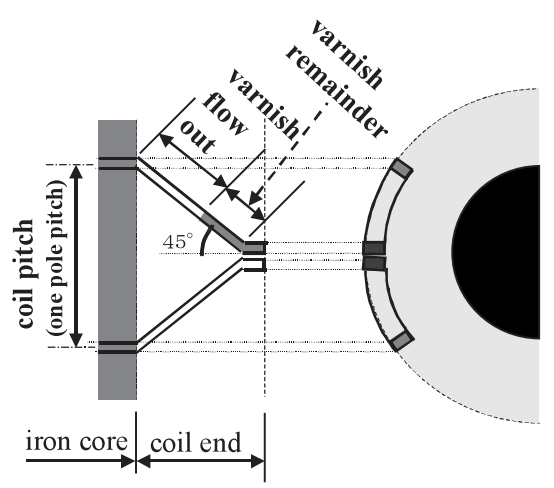

図 8 硬化時にワニス流出しやすいコイル位置

Fig. 8. Possible coil position of varnish flow out.

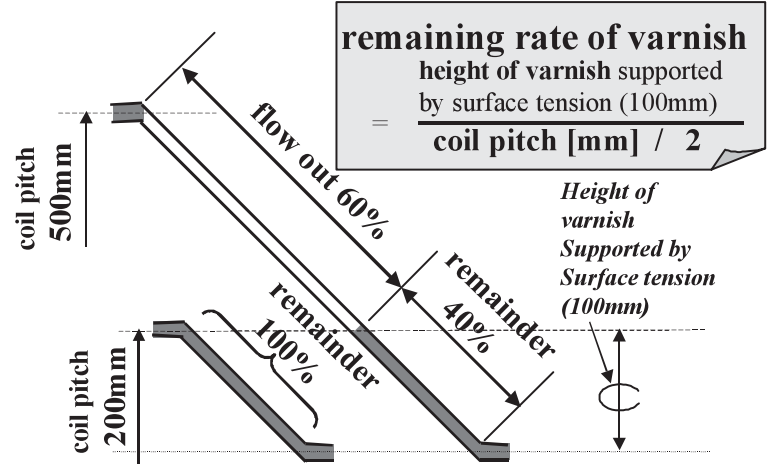

図 9 表面張力によるコイルエンドワニスの残留

Fig. 9. Varnish remainder at coil end with surface tension.

て, 再含浸 (真空含浸) 時の含浸時間 (加圧時間) の設定 の参考に供することができる。また表面張力試験の結果か らは，ワニス乾燥 (加熱硬化処理) 時に回転乾燥を適用す る場合，ワニスに対する遠心力と表面張力の釣合から，回 転乾燥の許容回転速度を得ることが出来る。

これらは比較的単純な演繹でであるので説明を省略し， 延命化のための含浸乾燥過程にとって, 特に重要と思われ る 2 点について, さらに検討する。

(1) 垂直コイルでのワニスの残留率ワニス乾燥時 は電機子 (回転子) を横置きとするので, 图 8 のように垂直 配置となるコイルが存在する。以下これを垂直コイルと呼 ぶことにすると，垂直コイルの上半分のハーフターンでは コイルエンド部のワニスの流出が生じやすいと考えられる。

今回の実験から，例えば $20 \mu \mathrm{m}$ のギャップの場合，図 9 に示すように高さで $100 \mathrm{~mm}$ ，コイルエンドに沿った長さ で $140 \mathrm{~mm}$ (コイルエンドの傾斜を 45 度とする) について は, 表面張力によりワニス流出を免れるという知見を得る。

特に小形機の場合には, 図 9 の付記のように,コイルピッ チが小さいので, コイルエンドの全長が表面張力で保持さ れる場合が考えられる。

（2） ワニス硬化時のワニスの流出速度の推定 ワニ ス硬化時には，後述するようにワニスの温度上昇にともな う一時的な粘度低下が生じる。このときのワニス流出を矩

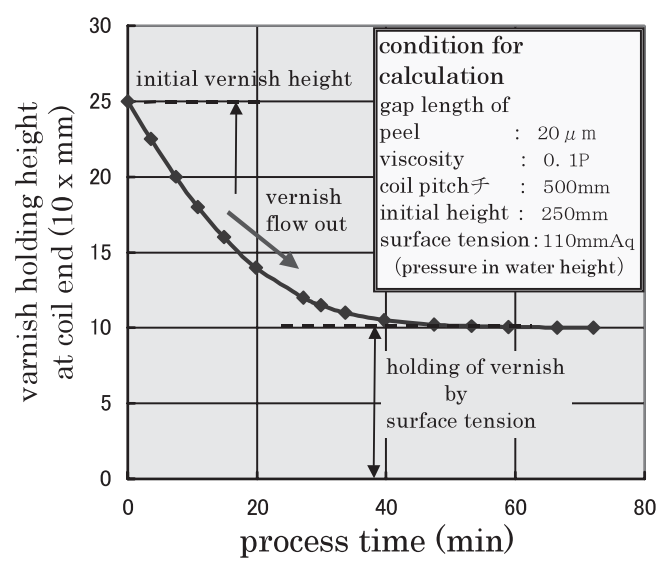

図 10 垂直位置コイルのワニス流出速度の理論 計算結果

Fig. 10. Theoretical calculation of varnish flow out speed in vertical position coil.

形管での流速の式 (付 4) 式を用いて算出する。

但し管の両端の差圧 $\Delta P$ として，剥離ギャップに浸透し たワニス重量から表面張力による保持力を差引いた值を用 いる。

このときワニスの残存高さ $x$ の減少を $x(t)$ と表すとき， 式の誘導は付録を参照するとして,$x(t)$ は次式で表される。

なお，以上の式に誘導過程を付録に示す。

$$
x(t)=A \cdot\left[\left(L_{1}-x\right)-L_{2} \cdot \log e\left\{\left(x-L_{2}\right) /\left(L_{1}-L_{2}\right)\right\}\right]
$$

但し $A=3 \eta\left(L_{1}-L_{2}\right) /\left(4 \delta_{2} \cdot \Delta P\right)$

$\eta:$ ワニスの粘度 [ポアズ]

$L_{1}:$ ワニスの初期高さ (コイルピッチの 1/2) [10 $\times \mathrm{mm}]$

$L_{2}:$ 表面張力が保持するワニス高さ $[10 \times \mathrm{mm}]$

である。

(1) 式での算出例を図 10 に示す。図は大形機を想定しコ イルピッチ $500 \mathrm{~mm}$, 剥離ギャップ $20 \mu \mathrm{m}$ ， ワニスの粘度 0.1 ポアズとした例である。図から流出時間 (40 分) は, 後 述するワニスの硬化時間 (ゲル化時間) に対応しており，垂 直位置のコイルではワニス流出が生じることか理論的に説 明されている。

\section{3. ワニスの硬化特性の試験と 評価}

〈3. 1〉 ワニスの硬化時間( ゲル化時間)の温度特性含 浸後の乾燥過程で一時的な粘度低下によるワニス流出の抑 制法を検討するにあたり，基礎特性として，ワニスの硬化 温度と硬化時間の関係を試験・確認した。

ここで「硬化」の用語は，加熱硬化時の流出抑制に着眼 している関係から，粘度が急上昇し液体から柔らかい固体 に急変する時点に対し使用しており，専門的にはゲル化又 は 1 次硬化というべきあるが，延命という設備技術的観点 から本研究を進めているので, 専門用語を回避している。 
温度制御を行うオーブンで $140^{\circ} \mathrm{C}, 150^{\circ} \mathrm{C}, 160^{\circ} \mathrm{C}$ の 3 段階の温度での硬化時間と硬化中のワニス温度を図 11 に 示す。

この実験は，ワニスを試験管に入れてオーブン中央部に 配置しワニス硬化させるものであるが，ワニス硬化 (ゲル 化）確認のため，予めピアノ線を試験管内ワニス中に入れ， ピアノ線をオーブンの扉を閉めた状態で外部から上下させ ることの出来る冶具を使用して, 試験管が持ち上がるのを オーブン前面ガラス空から確認し，硬化 (ゲル化) と判定 する方法を用いた (図 12 参照)。

硬化時間のスタートをワニス温度が所定の温度域に達す る運転開始 20 分後とすると, 各温度での硬化時間は

$140^{\circ} \mathrm{C}: 80 \mathrm{~min}$

$150^{\circ} \mathrm{C}: 50 \mathrm{~min}$

$160^{\circ} \mathrm{C}: 20 \mathrm{~min}$

となり，熱劣化と同樣に $10^{\circ} \mathrm{C}$ 半減則におおむね従うとみ ることが出来る。

なお図 11 には同一条件で行ったシリコンオイルの温度 上昇を点線で併記した。シリコンオイル温度とワニス温度 との差 (上昇分) は, ワニスの反応熱とみることが出来る。

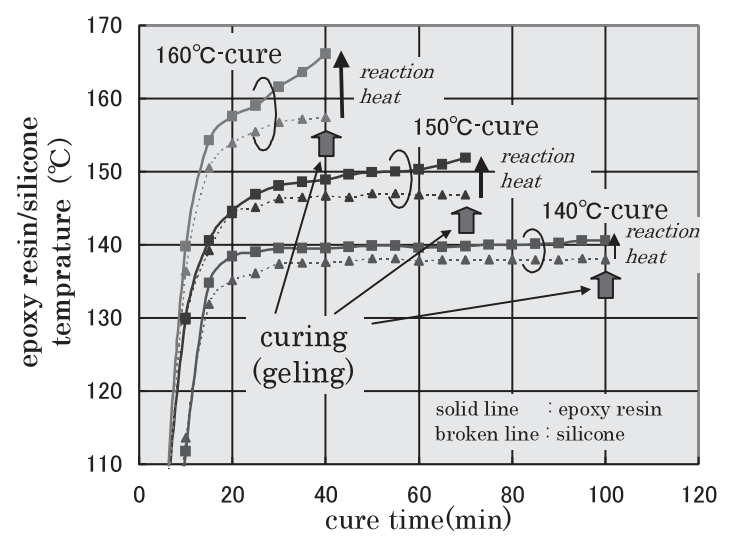

図 11 ワニス硬化温度と硬化時間の例

Fig. 11. An example of cure temperature versus cure time of varnish.

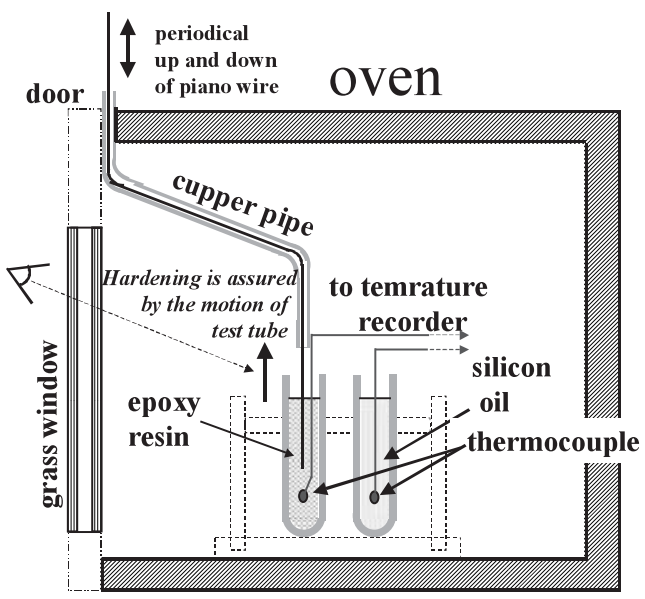

図 12 ワニス硬化試験装置

Fig. 12. Illustrated testing device for varnish cure.
この温度差の測定間隔 5 分ごとの累積和 (オーブンスター トから硬化まで) を求めて見ると

$140^{\circ} \mathrm{C}: 31.8^{\circ} \mathrm{C}$

$150^{\circ} \mathrm{C}: 29.8^{\circ} \mathrm{C}$

$160^{\circ} \mathrm{C}: 34.3^{\circ} \mathrm{C}$

となり，ほぼ同じ值になっている。

このことはワニスの硬化時に放出される反応熱(カロリー) が , 付録での検討の通り，ガラス転移点温度を超えていれ ば, 硬化温度によらず一定となっていることを示唆するも のと考えられる。

〈3. 2〉 ワニス硬化中の粘度変化の測定 $100 \mathrm{cc}$ の耐熱 ビーカーを用いて，湯煎方式でワニスを加熱して，硬化中 のワニスの温度と粘度の関係を測定した。

粘度測定には粘度デジタル表示の B 型粘度計を使用し， 湯煎にはシリコンオイルを使用した。

図 13 に弚の例を示す。

図は $130^{\circ} \mathrm{C}, 140^{\circ} \mathrm{C}, 150^{\circ} \mathrm{C}$ の結果比較としてあり，オー ブンでの試験結果と同樣に, 硬化時間はほぼ $10^{\circ} \mathrm{C}$ 半減と なっている。また図から，

1) 硬化 (ゲル化) 直前に粘度が急上昇すること

2) 20 分で一旦最低值を示すが，光の後は硬化直前まで 絶えず緩やかな上昇を続け，これは图 11 に見られる ワニス温度の緩やかな温度上昇に対応していること が明かである。

図 10 の垂直コイル位置でのコイルエンドワニス流出特 性の算出結果と比較すると，硬化中の粘度低下と关の持続 時間から，垂直位置のコイルでは上半分のコイルエンドの ワニス流出があり得ることが検証されている。

また本図から，硬化中の最低粘度が $20^{\circ} \mathrm{C} \sim 30^{\circ} \mathrm{C}$ 半減と みられるが, 硬化時間はほぼ $10^{\circ} \mathrm{C}$ 半減であるので, 硬化温 度高めに取るほうがワニス流出が抑制されると考えられる。

\section{4. 遠赤外線の適用試行とその評価}

遠赤外線の照射は，各種の方法が考えられるがここでは，

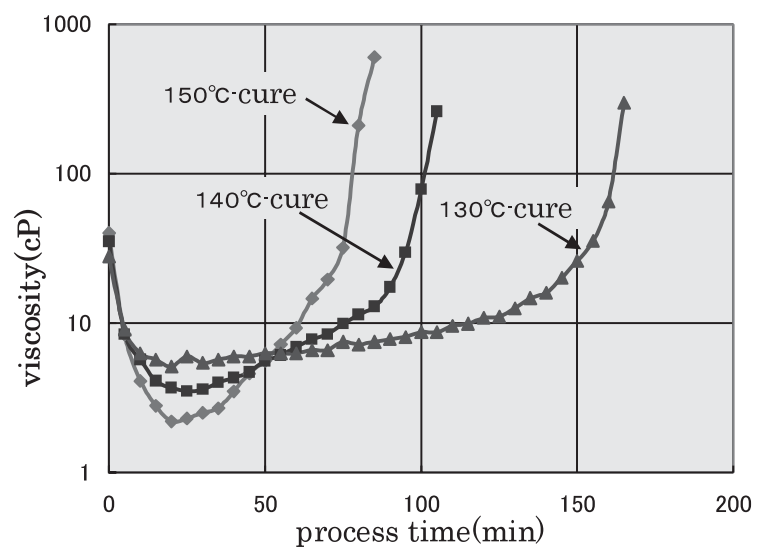

図 13 ワニス硬化中の粘度変化の一例

Fig. 13. An example of variation of viscosity during varnish cure. 


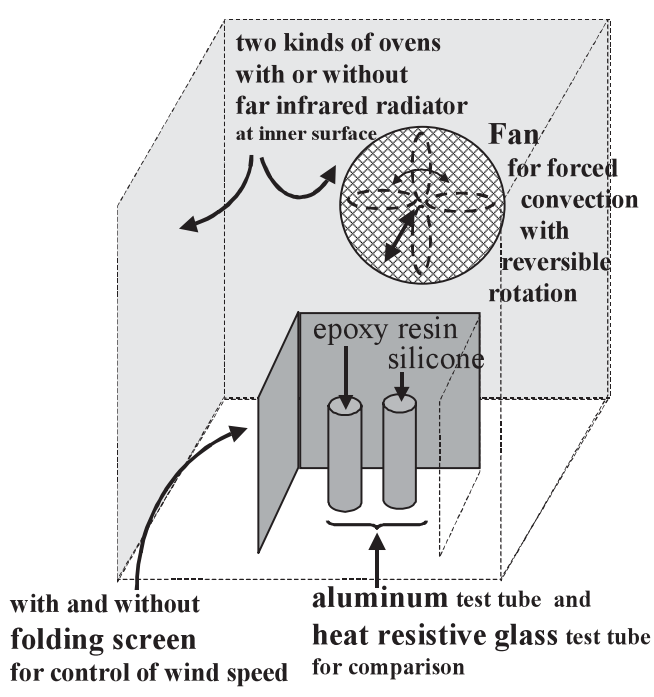

図 14 遠赤外線の効果検証用に改造された試験装置 Fig. 14. Testing device revised for additional experiment of infrared exposition.

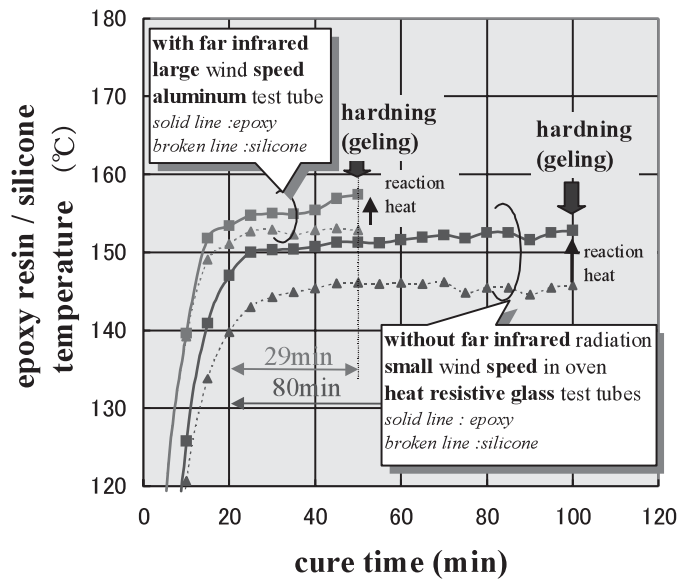

図 15 遠赤外線照射による硬化促進の一例

Fig. 15. An example of cure speed increase with infrared exposition.

同一オーブン内面が遠赤外線放射セラミックス処理のもの と無処理のもので比較した一例を示す。遠赤外線有り無し に加えて，オーブン内風速の大小および試験管管材にアル ミと耐熱ガラスの 2 者で比較実験しており，オーブン設定 温度はいずれも $150^{\circ} \mathrm{C}$ である。なお風速小の条件でオーブ ン内に衝立を設けたのは, 実機ワニス硬化の乾燥炉内風速 を実現するためである。

図 14 に試験装置の概念図を示す。

図 15 に 2 種 3 条件で合計 6 種類の条件の内 , 最速のケー スと最も遅いケース (通常の実験室での場合) の硬化時間 と硬化過程のワニス温度上昇の比較を示す。

最速のケースの硬化時間 (ゲル化時間) は, スタートか ら 20 分を差引くと 30 分であり, 最も遅い通常のケースは 80 分で, $150^{\circ} \mathrm{C}$ の同一設定温度にもかかわらず 2 倍以上の 差になっていることがわかる。

図中に図 11 と同樣にシリコンオイルの温度を併記した。

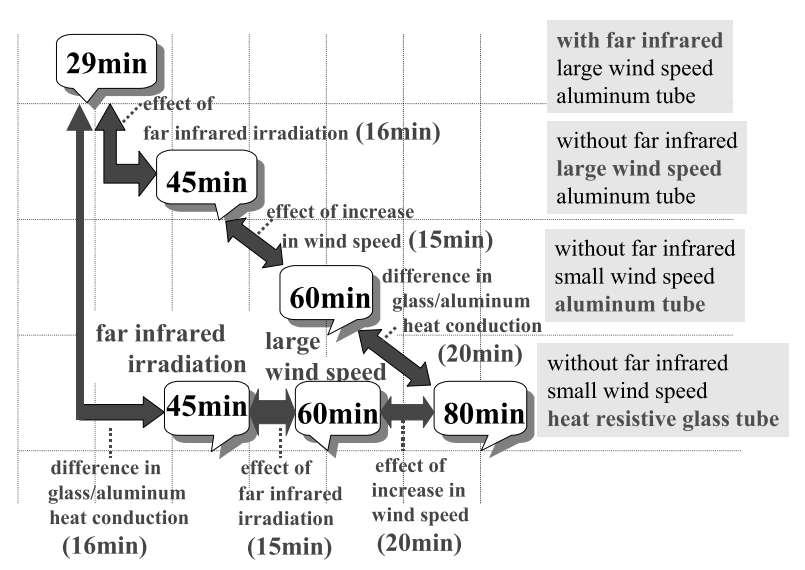

図 16 遠赤外線照射を含む効果促進マップ

Fig. 16. Mapped various cure process, including far infrared exposition.

ワニスとシリコンとの温度差をみるとアルミ管使用の場合 は温度差が少なく, ガラス管使用の場合は温度差が大きい。 付録( 5 )で検討の通り，ワニス硬化時に樹脂の硬化収縮・ 比熱 (熱容量) の減少に伴い発生する余剰熱量の総和すな わち反応熱量 (カロリー) を同一と仮定すると, 温度上昇 差はアルミとガラスの熱伝導熱伝達による熱抵抗差である と考えられる。硬化時間が長いガラスの場合は, 単位時間 当たりの熱流出は少ないが，熱抵抗大のため熱流出と熱抵 抗の積である温度上昇がアルミの場合より大きいと考えら れる。

図 16 では, 2 種 3 条件, 計 6 ケースの硬化時間のマッ プを示した。これにより遠赤外線による硬化時間短縮効果， オーブン内風速アップによる硬化時間短縮効果, ガラス ・ アルミの熱伝導性による硬化時間の差が明らかである。

特に最後の点は, 実機硬化時に, 乾燥炉内で遠赤外線を 受けて効率よく熱を吸収した整流子面からライザー経由で 熱が銅帯中を伝導することによって，コイルの素線近傍が， 主絶縁部より先に硬化することを示唆している。

\section{5. あとがき}

現在 , 寿命期を迎えている多数の大形直流機の延命化の キーテクノロジーとして期待されている電機子コイルへの 再含浸を確実にするため含浸乾燥の基礎特性を実験と理論 から明らかにし, また遠赤外線の利用による硬化促進につ いてのフィージビリティースタディーを行った。この結果 は再含浸の確実性向上への新手法に直接展開するもので, 今 後は再含浸の新方法の開発・検証を行っていく予定である。 (平成 15 年 9 月 19 日受付, 平成 16 年 1 月 5 日再受付)

$$
\text { 文献 }
$$

(1) S. Kiyokasa, H. Inoue, H. Hirose, and N. Morita: "An experimental study of impregnation characteristics for aged dc machine to extend its life and feasibility study for application of far infrared radiation for the process", in Papers of Technical Meeting on Rotating Machinery, IEE of Japan, No.RM02-28 (2002) (in Japanese) 
清川 晋・井上晴雄・廣瀬治男・森田 登:「直流機延命化の再含浸 基礎特性と遠赤外線適用フィージビリティースタディー」, 電気学会 回転機研資, RM-02-28 (2002)

(2) Y. Hayashi: "Recent technology and its problem of preventive maintenance for DC machines", in Papers of Technical Meeting on Rotating Machinery, IEE of Japan, No.RM-91-06 (1991) (in Japanese)

林：「直流機における予防保全の現状と課題」, 電気学会回転機研資, RM-91-06 (1991)

(3) DC Machine committee of Life Diagnosis Technology: "Life Diagnosis Technology of DC Machine", Technical Report, No.594, IEE of Japan (1995) (in Japanese)

直流機寿命診断技術調査専門委員会 :「直流機の寿命診断技術」, 電 気学会技術報告, No.594 (1995)

(4) Editor Committee for Diagnosis Technology of Electric Apparatus: "Diagnosis Technology of Electric Apparatus", IEE of Japan (1989) (in Japanese) 電気設備の診断技術編修委員会 : 「電気設備の診断技術」, 電気学会 (1989)

(5) S. Isobe, K. Matsunobu, and H. Mitsui: "Practical Insulation of Electric Machinery", Kaihatsu-sha, 3055-400410-1060 (1988) (in Japanese) 磯部・松延・三井 : 電気機器絶縁の実際, 開発社 (1988)

(6) Japan Institute of Plant Maintenance (H. Toko and K. Ito): "Maintenance of Motors", Japan Institute of Plant Maintenance, ISBN4-88956-107-2C3054 (1995) (in Japanese)

登古・伊藤 : 電動機のメンテナンス, 日本プラントメンテネナンス 協会 (1995)

( 7 ) H. Sequentz, (Japanese Translation: H. Mitsui, M. Matsui, and K Matsunobu): Hellstellung der Wicklungen electrischer Machinen, Kaihatsusha, 3053-41100-1060 (1990) (in Japanese)

三井・松井・松延 訳 : 電機コイルの製作と保守, 開発社 (1990)

付 録

\section{（1） 円管モデルでのワニスの浸透時間}

半径 $r$, 長さ $L$ の円管の両端に差圧 $\Delta P$ を加えたとき粘 度 $\eta$ の液体が円管が通る流速 $V$ はハーゲンポアズイユの式 から

$V=\left(r^{2} / 8 \eta\right)(\Delta P / L)$

ただし $V:$ 平均流速 $(\mathrm{cm} / \mathrm{s}), r$ : 管の半径 $(\mathrm{cm})$ ここでは $r$ にギャップ長の值を代入,$\eta$ : 粘度 (ポ アズ) $\Delta P:$ 差圧 $\left(\mathrm{dyn} / \mathrm{cm}^{2}\right), L$ : 円管の長さ (ワ ニス浸透距離, $\mathrm{cm})$

录離した絶縁層へのワニス浸透の場合，浸透距離 $x$ が大 きくなると $x$ に反比例して流速が低下する。従ってワニス 浸透距離を $x[\mathrm{~cm}]$ とすると, 上式 $L[\mathrm{~cm}]$ が $x$ に置換され， 流速 $V[\mathrm{~cm} / \mathrm{s}]=d x / d t$ であるので(付 1 ) 式は，

$$
d x / d t=\left(r^{2} / 8 \eta\right)(\Delta P / x)
$$

となり，

$$
t=\int_{0}^{t} d t=\frac{8 \eta}{\Delta P \cdot r^{2}} \int_{0}^{x} x d x
$$

これを積分すると

$$
t=\left\{4 \eta /\left(\Delta P \cdot r^{2}\right\} \cdot x^{2}[\mathrm{~s}]\right.
$$

を得る。

\section{（２）矩形ギャップのモデルでのワニスの浸透時間}

矩形ギャップの場合の平均流速 V の式を(付 4) 式に示 す。同式はポアズイユの式と似ているが，約 10 倍になる。

$$
V=\left(g^{2} / 8 \eta\right)(\Delta P / L)(32 / 3)[\mathrm{cm} / \mathrm{s}]
$$

ただし $g:$ ギャップ長 $(\mathrm{cm})$, 光の他記号はポア

ズイユの式に同じ

剥離した絶縁層へのワニス浸透の場合は，円管の場合と 同樣，管の長さ $L$ をワニス浸透長 $x[\mathrm{~cm}]$ で置換え，平均流 速 $V=d x / d t$ として置換すると

$$
d x / d t=\left(4 g^{2} / 3 \eta\right) \cdot(\Delta P / x)
$$

を得る。これを積分すると

$$
t=\left\{3 \eta /\left(8 g^{2} \cdot \Delta P\right)\right\} \cdot x^{2}[\mathrm{~s}] .
$$

となる。

（３）表面張力によりギャップに沿って垂直方向にワニス が浸透していく場合にワニス浸透につれて浸透速度が低下 していく過程を表現する式の誘導

この場合は表面張力で最終的に到達する浸透長 (垂直方 向）を $L_{0}$ ，任意時点の浸透長を $x$ とするとき，任意の時点 での表面張力と浸透したワニスの自重の差を圧力換算し， 差圧 $\Delta P$ とするとき， $\Delta P$ は表面張力による初期の圧力 $\Delta P_{0}$ と $\left(L_{0}-x\right) / L_{0}$ の積で比例する。従って $\Delta P$ は，

$$
\Delta P=\Delta P_{0} \cdot\left(L_{0}-x\right) / L_{0}\left[\mathrm{dyn} / \mathrm{cm}^{2}\right] .
$$

となる。このとき，

$$
d x / d t=\left(4 g^{2} / 3 \eta\right) \cdot\left(\Delta P_{0} / x\right) \cdot\left(L_{0}-x\right) / L_{0} \ldots \cdots \text {. (付 8) }
$$

となり，

積分結果は，

$$
\begin{aligned}
t= & -3 \eta \cdot L_{0} /\left(4 g^{2} \cdot \Delta P_{0}\right) \\
& \times\left[L_{0} \cdot \ln \left\{\left(L_{0}-x\right) / L_{0}\right\}+x\right][\mathrm{s}]
\end{aligned}
$$

となる。

（4） ワニス流出の計算

この場合 $x=L_{0}$ でワニス自重と表面張力が釣合いワニス 流出が停止するが, 途中の任意の時点では $x>L_{0}$ である。 ここで差圧 $\Delta P$ は負であるとし， $x=L_{0}$ の時点で表面張力 とワニス自重が釣合い差圧 $\Delta P=0, x>L_{0}$ の任意の $x$ で は $\Delta P$ が $\Delta P_{0}$ と $\left(x-L_{0}\right) / L_{0}$ との積であるとして ，

$$
\Delta P=-\Delta P_{0} \cdot \frac{x-L_{0}}{L_{0}} \ldots \ldots \ldots \ldots \ldots \ldots \ldots \ldots \ldots(\text { 付 } 10)
$$

とする。このとき(3)の (付 8) 式に相当する式は下式に なる。

$$
\frac{d x}{d t}=(-1) \cdot \frac{4 g^{2} \cdot \Delta P_{0}}{3 \eta x} \cdot \frac{x-L_{0}}{L_{0}}
$$

従って積分式は

$$
t=(-1) \cdot \frac{3 \eta L_{0}}{4 \Delta P_{0} \cdot g^{2}} \int_{x_{0}-L_{0}}^{0}\left\{1+\frac{L_{0}}{X}\right\} d X \cdots \cdots \text { ( 付 }
$$

となる。ただし $x_{0}$ はワニスの初期浸透長，すなわちコイル エンド長さである。また $X$ は積分の都合上変数を置き換え たもので， $X=x-L_{0}$ である。積分結果は，下記となる。 


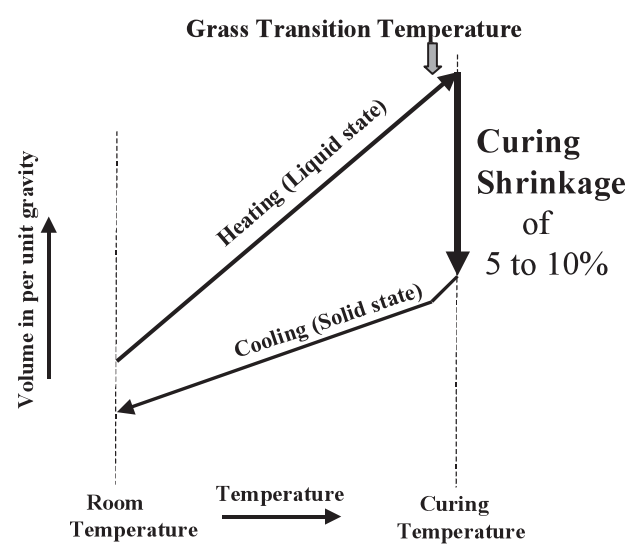

付図 1 エポキシ樹脂の硬化収縮の概念図 app. Fig. 1. Schematic diagram of curing shrinkage in epoxy resin.

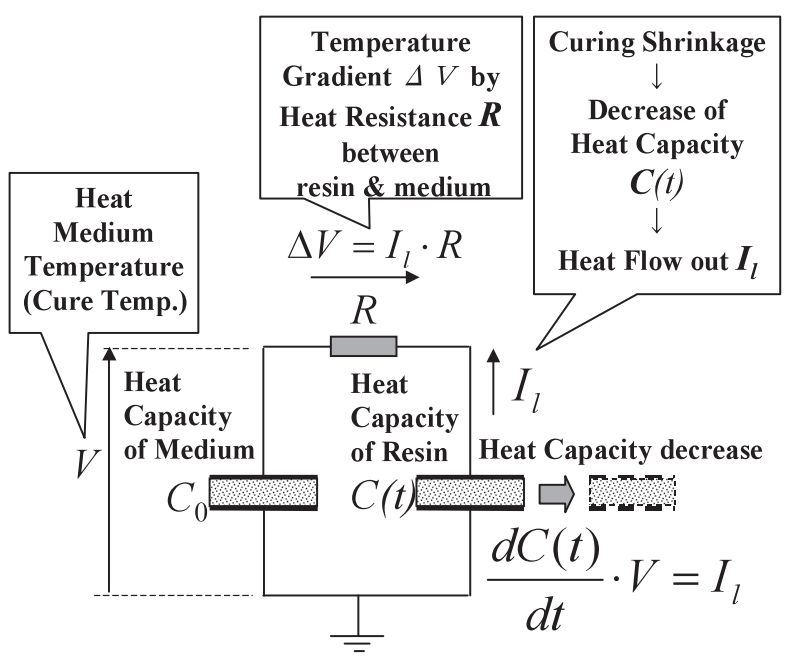

付図 2 等価回路による反応熱の生成原理

app. Fig. 2. Principle of reaction heat illustrated by equivalent circuit.

$$
t=\frac{3 \eta L_{0}}{4 \Delta P_{0} \cdot \delta^{2}}\left[\left\{x_{0}-x\right\}+L_{0} \cdot \ln \left\{\frac{x_{0}-L_{0}}{x_{0}-L_{0}}\right\}\right]
$$

（５）エポキシ樹脂硬化時の反応熱について

エポキシ樹脂等熱硬化性樹脂ではガラス転移点温度を超 えると架橋反応と呼ばれる三次元メッシュ構造の結合生成 が始まり, 液体から固体に変化していく。このとき付図 1 に示す硬化収縮が生じ , 同時に比熱が低下する。

比熱が低下すると熱容量が低下するため樹脂から余剩の 熱 (カロリー) ガ外部 (以下熱媒体) に逃げていく結果と なる。

加熱硬化させるための熱媒体と樹脂の間に容器の熱伝導 熱伝達などの熱抵抗があるので，余剰の熱の流出に際，こ の熱抵抗による温度勾配 (温度差) が生じて，樹脂温度は 熱媒体温度より上昇する。この温度上昇は硬化収縮反応と 同時に見られるので反応熱と呼ばれている。

付図 2 は反応熱の生成を電気に置換え，等価回路で説明 したものである。
熱媒体温度 (本論文, 図 11 の例では $140,150,160^{\circ} \mathrm{C}$ ) を変化させても, 最終的な硬化収縮量 (付図 1 参照), 熱容 量変化は同一である。硬化時間長く掛かる $140^{\circ} \mathrm{C}$ の場合は 架橋の生成速度が遅く, 従って収縮速度, 比熱・熱容量の 減少速度が遅くなる。光の結果, 単位時間当たりの熱（力 ロリー）の流出が少なくなるので熱媒体と樹脂の温度勾配 (温度差) は小さくなるが, 硬化時間が長くなるので熱媒体 と樹脂との温度差の時間積分值は硬化温度によらずほぼ同 一になると考えられる。

また図 16 におけるガラス管とアルミ管の場合のように， 樹脂と熱媒体との間の熱抵抗が異なる材質で反応熱を比較 すると下記のようになる。硬化時間が同一で, 単位時間当 たりの熱の流出が同一である場合には, 樹脂と熱媒体の温 度勾配 (温度差) は熱抵抗に比例して大きくなる。図 16 の 最も硬化時間の長い (ガラス管使用の) 場合は, 最速の (ア ルミ管使用の) 場合と比べて，硬化時間の増加による熱流 出の低下をアルミ $\rightarrow$ ガラスの熱抵抗の増加が上回ってい るため, 樹脂と熱媒体との温度差が, 最速のアルミの場合 より, 大きくなっていると考えられる。

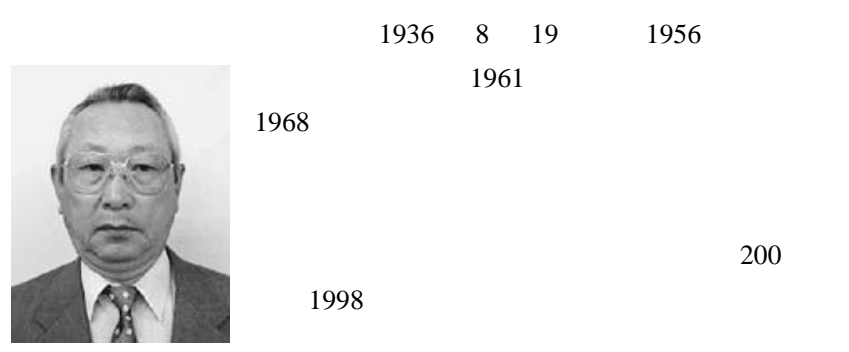

井上晴 雄 (非会員) 1955 年 9 月 28 日生。1 974 年 3 月埼玉 県立春日部工業高等学校卒業。1991 年 7 月 , ミサ 卜 (株) 入社。主として床暖房システム, 遠赤外 線応用システムの開発に従事。現在, 同社開発部。

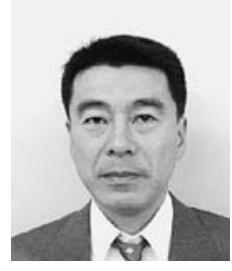

廣 瀬 治 男 (正員) 1937 年 9 月 23 日生。1 963 年 3 月慶応

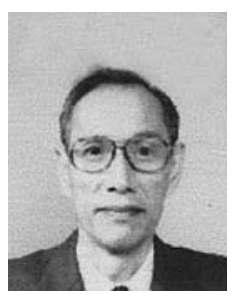
義塾大学大学院工学研究科電気工学専攻修士課程 修了。工学博士。現在, 日本工業大学工学部電気 電子工学科教授。電子物性と素子, 通信と信号処 理, 超伝導材料と応用に関する研究に従事。電子 通信学会, 応用物理学会, IEEE, AAAS, NYAS 会員。

森田登 (正員) 1946 年 10 月 3 日生。1975 年 3 月慶應義

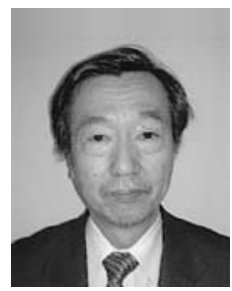
塾大学大学院工学研究科電気工学専攻博士課程修 了。1975 年東芝入社。以来直流機開発設計・整流 現象解析・絶縁診断技術開発等に従事。1990 年 4 月より日本工業大学工学部電気電子工学科教授。 工学博士。現在, 電気学会直流機延命化技術実用 化調査専門 (委) 委員長。 